\title{
Phage pilHa: a Phage Which Adsorbs to IncHI and IncHII Plasmid-coded Pili
}

\author{
By J. N. COETZEE, ${ }^{*}$ D. E. BRADLEY, ${ }^{2}$ JEANETTE FLEMING, ${ }^{2}$ \\ LAUREEN DU TOIT, ${ }^{1}$ VICTORIA M. HUGHES ${ }^{3} \dagger$ AND R. W. HEDGES 4 \\ ${ }^{\prime}$ Department of Microbiology, University of Pretoria and Bacterial Genetics Research Unit of the \\ South African Medical Research Council, PO Box 2034, Pretoria 0001, South Africa \\ 2 Faculty of Medicine, Memorial University of Newfoundland, St John's, \\ Newfoundland AIB 3V6, Canada \\ ${ }^{3}$ Department of Bacteriology, Royal Postgraduate Medical School, Hammersmith Hospital, \\ London WI2 OHS, UK \\ ${ }^{4}$ Plant Genetic Systems, J. Plateaustraat 22, B-9000 Gent, Belgium
}

(Receired 22 October 1984; revised 7 December 1984)

\begin{abstract}
Phage pil $\mathrm{H} \alpha$ was specific for bacterial strains, of various genera, harbouring plasmids of the $\mathrm{HI}$ and HII incompatibility groups. Plaque formation was temperature sensitive in that plaques formed at $26^{\circ} \mathrm{C}$ but not at $37^{\circ} \mathrm{C}$. Plaques were fairly clear, irregular in outline and varied from pin point to about $2 \mathrm{~mm}$ in diameter on all hosts where plaques were detected. The phage had an isometric hexagonal outline with a diameter of $25 \mathrm{~nm}$. It contained RNA but differed from all but one other plasmid-dependent RNA phage by being sensitive to chloroform. It adsorbed along the length of the shafts of IncHI and HII plasmid-coded pili.
\end{abstract}

\section{INTRODUCTION}

The IncH group of plasmids (Grindley et al., 1972; Anderson \& Smith, 1972) was subdivided into $\mathrm{H}_{1}$ and $\mathrm{H}_{2}$ because, although incompatible, the groups share minimal DNA homology. These groups are now designated $\mathrm{H} 1$ and $\mathrm{H} 2$ (Taylor \& Grant, 1977). Plasmid MIP233 which, despite being incompatible with both the latter groups (Le Minor et al., 1976), also has little DNA homology with them and was allocated to Inc group H3 (Roussell \& Chabbert, 1978).

Plasmids of these $\mathrm{H}$ subgroups have molecular masses which range from $110 \mathrm{MDal}$ to $170 \mathrm{MDal}$ (Anderson et al., 1975; Bradley et al., 1982a) and transfer by conjugation occurs at low frequencies (Grindley et al., 1972; Bradley et al., 1980) (but see below). The transfer process is thermosensitive (Williams Smith, 1974; Taylor \& Levine, 1980). Some IncH1 plasmids displace the $\mathrm{F}$ plasmid from Escherichia coli $\mathrm{K} 12 \mathrm{~F}^{+}$despite the fact that they share minimal DNA homology with the latter plasmid (Smith et al., 1973) and $\mathrm{H} 2$ plasmids inhibit the growth of a number of bacteriophages (Taylor \& Grant, 1976).

Pili specified by $\mathrm{H} 1$ and $\mathrm{H} 2$ plasmids are of the thick flexible variety, belong to morphological group 1 and are serologically related (Bradley, 1980 b). Pili of H3 plasmids have not yet been identified (Bradley et al., 1980, 1982a).

Plasmids pHHI457 and pHH1508a are incompatible, have masses of 110 and $100 \mathrm{MDal}$ respectively and code for the constitutive production of thick flexible pili which are serologically related to those produced by the $\mathrm{H} 1$ and $\mathrm{H} 2$ plasmid groups (Bradley et al., 1982a). Conjugative transfer of plasmids $\mathrm{pHH} 1457$ or $\mathrm{pHH} 1508$ a to $\mathrm{IncH} 1, \mathrm{H} 2$ or $\mathrm{H} 3$ plasmid-containing strains is not thermosensitive and the plasmids are compatible with plasmids of all three IncH subgroups (Bradley et al., 1982a). Because of the morphological and serological similarity of pili coded for

† Present address: 9, Ash Grove, Weedon Lane, Amersham, Bucks., UK. 
by plasmids of the IncH groups and by $\mathrm{pHH} 1457$ and $\mathrm{pHH} 1508 \mathrm{a}$ it was decided to make the latter plasmids prototypes of a new group, IncHII and, by analogy with IncF, to name the original IncH plasmids IncHI with subgroups HI1, HI2 and HI3 (Bradley et al., 1982a). Two more members of the IncHII group, pHH1532b-1 and pMG110, have recently been identified (Bradley et al., 1982a; Wolfson et al., 1982).

IncH plasmids harboured by human pathogenic bacteria are an important cause of antibiotic resistance exhibited by these strains and create therapeutic problems (Anderson, 1975; Bradley et al., 1982a). The mechanisms involved with the temperature sensitivity of conjugative transfer of HI plasmids (Taylor, 1983), the high-temperature elimination of some IncHI plasmids (Taylor \& Levine, 1980; Williams Smith et al., 1978) and processes concerned in the displacement of IncF plasmids by plasmids of the HIl group (Smith et al., 1973) are other important areas requiring further work.

A phage adsorbing specifically to IncH plasmid-coded pili has not yet been described. Such a phage could be of use in the above experiments by monitoring production of these pili by bacteria and could possibly even be considered for use as a therapeutic agent (Williams Smith \& Huggins, 1983; Editorial, 1983). Here we describe the properties of phage pilH $\alpha$ which was isolated from sewage as lysing $E$. coli strain JE2571(pHH1508a) but not the isogenic strain lacking the plasmid.

\section{METHODS}

Bacteria and plasmids. The Escherichia coli K12 strains were J53, J53-2, J62-1 (Datta et al., 1980) and JE2571 (Bradley, 1980a). Klebsiella pneumoniae strain Gl62 and K. oxytoca strains G147 and G147-1 were provided by Dr I. Simpson, Glaxo Group Research, Greenford, Middlesex, UK. The Salmonella typhimurium strain was M827-2, a spontaneous rif mutant of LT2 strain M827 (Spratt et al., 1973). Serratia marcescens Sr41 (Matsumoto et al., 1973) was provided by $\mathrm{Dr}$ H. Matsumoto. Sr4l-2 is a spontaneous rif mutant of the latter strain (J. N. Coetzee, unpublished). Proteus mirahilis strain PM5006nal (Coetzee, 1974) and P. morganii 2815nal-r (Coetzee et al., 1979) were also used. Plasmids originated from the collection of Naomi Datta (Datta, 1977, 1979) with the exceptions of pDT933, which was kindly supplied by D. E. Taylor (Taylor, 1983) and pMG110 (Wolfson et al., 1982), which was sent by D. C. Hooper, J. S. Wolfson and M. N. Swartz. Apart from plasmids belonging to the IncHI incompatibility group (see Table 1), only those which encoded constitutive pilus synthesis (as judged by a transfer frequency of $>1 \times 10^{-3}$ per donor $\mathrm{h}$ or by plaque formation by appropriate plasmid-specific phages) were used. Thus one or more plasmids belonging to Inc groups B (Coetzee et al., 1982), C (Sirgel et al., 1981), FI to FIV (Jacob et al., 1977), F lac (Bradley et al., 1981 b), HII (Bradley et al., 1982a), $\mathrm{I}_{1}, \mathrm{I}_{2}$ (Coetzee et al., 1982), J (Bradley et al., 1982 b). N. P (Coetzee et al., 1979), t (Bradley et al., 1981 c), W (Coetzee et al., 1979) and X (Bradley et al., 1981 a) were used. J62-1(P/acR Idrd19) (Sirgel et al., 1981) and J53(R6K) (Bradley et al., 1981 a) were the indicator strains for phages $C-1$ and $X$ (see below) respectively. Plasmid-carrying strains were maintained on selective antibacterial drug-containing media to minimize plasmid segregation (see Bradley et al., 1982a).

Bacteriophages. Lysis of bacterial strains by plasmid-specific phages MS2 (Davis et al., 1961), C-1 (Sirgel et al., 1981), F lac (Bradley et al., 1981 b), PR64FS (Coetzee et al., 1980), J (Bradley et al., 1982 b), M (Coetzee et al., 1983), PR772 (Coetzee et al., 1979), t (Bradley et al., 1981 c) or X (Bradley et al., 1981 a) was used to demonstrate constitutive pilus production by strains carrying appropriate plasmids. Phages $\mathrm{C}-1$ and $\mathrm{X}$ were also used as controls in RNAase-chloroform and diethyl ether sensitivity tests. The former phage is sensitive to RNAase but resistant to the organic solvents (Sirgel et al., 1981), while the latter is resistant to RNAase and diethyl ether but sensitive to chloroform (Bradley et al.. 1981a).

Media. antihacterial agents, general phage techniques, transfer of plasmids by conjugation, organic solvent and ribonuclease sensiticity of phage and production of phage lysates by a soft agar layer technique. These were done as described and referred to by Coetzee et al. (1979), Bradley et al. (1980, 1981a), Ackermann et al. (1978) and Hershey et al. (1943). Broth and the overlay agar contained the particular plasmid-selective antibacterial agents (Bradley et al., 1982a). Conjugative transfer of IncHI plasmids was done at $26^{\circ} \mathrm{C}$ (Taylor \& Levine, 1980). Phage isolation and initial experiments with phage pilH $\alpha$ (see below) were performed at an incubation temperature of $37 \mathrm{C}$. When it became apparent that plaque formation by this phage was temperature sensitive, all further experiments were conducted at $26^{\circ} \mathrm{C}$ unless otherwise stated.

Phage isolation. Attempts were made to isolate an IncHII plasmid-specific phage from sewage specimens obtained from various sewage works in the Pretoria area according to the method of Bradley et al. (1981 a). One pair of partner strains used for sewage enrichment was JE2571 and M827-2 carrying plasmid pHH1457, the second set comprised the same hosts carrying plasmid pHHI 508a and plasmid pHH $1532 \mathrm{~b}-\mathrm{l}$ in the two hosts made the third set. After the incubation period, enriched sewage filtrates were spotted separately on soft agar lawns of all the above strains individually as well as on isogenic organisms lacking plasmids. Plating the filtrates on the same 
strain used for enrichment ruled out selection (see Meynell \& Lawn, 1968) but was adopted in view of the host specificity of certain plasmid-specific phages (see Coetzee et al., 1979; Sirgel et al., 1981; Bradley et al., 1981 c, $1982 b ;$ J. N. Coetzee, unpublished results).

Bacteriophage propagation. Propagation of phage pilH $\alpha$ (see below) was done as described by Bradley et al. (1981 $a$; see also Coetzee et al., 1982). Briefly, an exponentially growing culture of the donor plasmid-bearing organisms under test $(0.1 \mathrm{ml})$ was mixed with an equal volume of stationary phase plasmid-free isogenic recipient on a Millipore membrane resting on nutrient agar. After overnight incubation, the growth was gently washed off by suspending the membrane in $5 \mathrm{ml}$ warm broth. To $1 \mathrm{ml}$ of this broth suspension, possibly containing transconjugants temporarily derepressed for pilus synthesis (see Bradley \& Fleming, 1983), were added $0 \cdot 1 \mathrm{ml}$ phage suspension $\left(1 \times 10^{10}\right.$ p.f.u. $\left.\mathrm{ml}^{-1}\right)$ and $4 \mathrm{ml}$ of melted soft top-layer agar and the mixture was poured over the surface of a nutrient agar plate and allowed to set. After overnight incubation, the phage was harvested and the titre on strain JE2571(pHH1508a) determined. This titre was compared to that obtained in a similar experiment using the same recipient but no donor. A phage titre increase of at least 10 -fold that of the negative control, in two separate experiments, was taken as a positive result. Experiments which yielded negative or doubtful results were repeated on at least a further two occasions.

Concentration of phage. The optimal final concentrations of polyethylene glycol (mol. wt 6000 ) and $\mathrm{NaCl}$ (Yamamoto et al., 1970) for concentrating phage pilH $\alpha$ (see Results) were $11 \%(\mathrm{w} / \mathrm{v})$ and $0.5 \mathrm{M}$ respectively. Pellets were suspended in small volumes of distilled water.

Electron microscopy. Negative staining for electron microscopy was done as described by Bradley et al. $(1981 a, b, c)$.

\section{RESULTS}

\section{Transfer of plasmids}

IncHII plasmids pHH1457, pHH1508a and pHH1532b-1, and IncHI plasmids pDT933 and R478 (Table 1) transferred between various $E$. coli $\mathrm{K} 12$ strains and these strains to Klebsiella strains G162 and G147, S. typhimurium M827-2, Sr. marcescens Sr71-2 or P. morganii 2815 nal-r at frequencies of $>3 \times 10^{-3}$ transconjugants per donor $\mathrm{h}^{-1}$. Plasmids R27, R726, pW23 and MIP233 transferred from $E$. coli $\mathrm{K} 12$ strains to the above hosts at frequencies between $5 \times 10^{-7}$ and $1 \times 10^{-5}$ transconjugants per donor $\mathrm{h}^{-1}$. None of the above plasmids transferred from the E. coli hosts to $P$. mirabilis 5006 nal (frequency $<1 \times 10^{-7}$ transconjugants per donor $\mathrm{h}^{-1}$ ). The host range of plasmids may be limited to particular hosts (Datta \& Hedges, 1972; Hedges \& Jacoby, 1980) and the present case may be another example.

Whereas the transfer of the IncHI plasmids is temperature sensitive (Williams Smith, 1974; Williams Smith et al., 1978; Anderson, 1975; Taylor \& Levine, 1980; Bradley et al., 1980; Taylor, 1983), temperature sensitivity has not been reported for the conjugative transfer of the IncHII plasmids $\mathrm{pHH} 1532 \mathrm{~b}-1$ and pMG110. Plate matings with plasmid-bearing derivatives of $K$. oxytoca strain $\mathrm{Gl} 147$ and strains of $E$. coli $\mathrm{J} 62-1$ as recipients yielded transfer frequencies of $>5 \times 10^{-2}$ transconjugants per donor $\mathrm{h}^{-1}$ for both plasmids in experiments conducted at $26^{\circ} \mathrm{C}$ and $37^{\circ} \mathrm{C}$.

\section{Isolation of a pHH1508a-dependent bacteriophage}

From sample no. 361 of sewage examined over a period of 3 years and enriched with strain M827-2(pHH1508a), a phage was isolated on JE2571(pHH1508a) which formed plaques on these two strains but not on isogenic organisms lacking the plasmid. Because of the adsorption site and host range (see below) and to allow for different, as yet undiscovered, phages also active on IncH plasmid-carrying strains, it was named phage pilH $\alpha$.

\section{Properties of phage pilH $\alpha$}

Plaque formation and morphology. A problem present from the start was the inconsistency with which strains supported plaque formation by the phage. The fact that the phage also plated (intermittently) on bacteria carrying IncHI plasmids (see below) which are temperature sensitive for transfer, prompted an investigation of the possibility that plaque formation was a temperature sensitive process. Phage spot tests were accordingly done with all strains previously used carrying IncHI or IncHII plasmids and with seeded pre-warmed plates at $26^{\circ} \mathrm{C}$ and $37^{\circ} \mathrm{C}$. Immediately after spotting the phage the uncovered plates were returned to empty incubators 


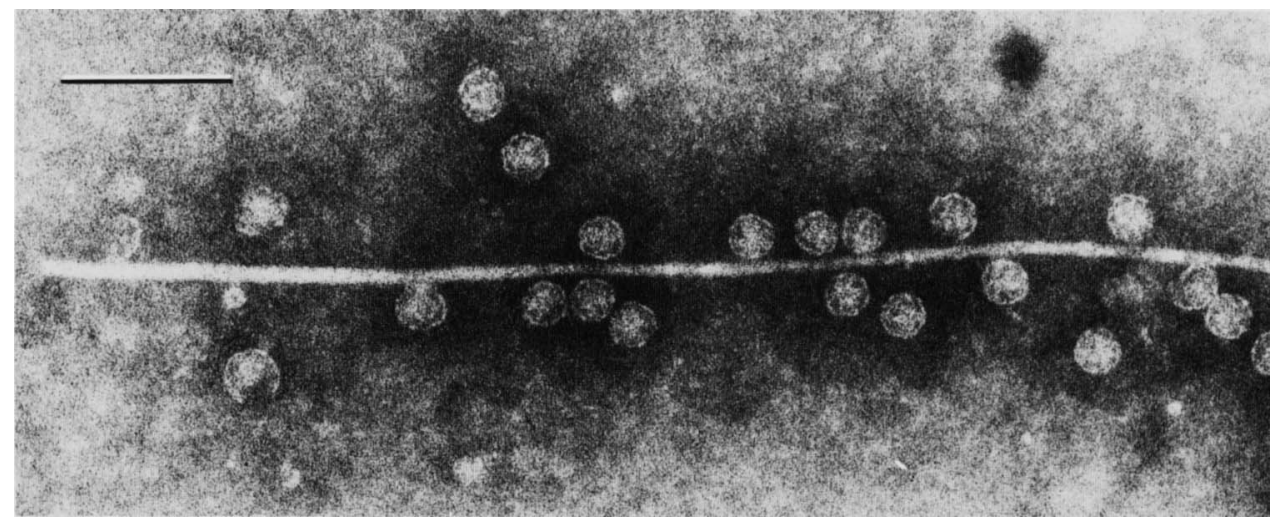

Fig. 1. Phage pilH $\alpha$ virions adsorbed to an IncHII pilus synthesized by $K$. oxytoca strain G147I(pMG II0). Many phage plus pilus complexes were found in phage suspensions made by extracting confluently lysed plates. Detached virions found near the pili were probably reversibly adsorbed and separated during drying. Phage pilH $\alpha$ appears similar to other RNA phages. Bar, $100 \mathrm{~nm}$.

maintained at the above temperatures. The incubators never contained more than eight plates singly placed and these were then incubated overnight after quickly replacing the Petri dish lids once the drops of phage had dried. The phage only lysed bacteria maintained at $26{ }^{\circ} \mathrm{C}$. There was no visible action at $37^{\circ} \mathrm{C}$. Further experiments determined the critical temperature to be about $31{ }^{\circ} \mathrm{C}$ (not shown). Adopting a temperature of $26^{\circ} \mathrm{C}$ for all further experiments removed all inconsistencies from the plating procedure. Plaques on bacterial lawns which had been incubated overnight at $26^{\circ} \mathrm{C}$ were fairly clear and varied from about $2 \mathrm{~mm}$ in diameter to pin point. The larger plaques were irregular in outline

Phage morphology and adsorption site. Phage pilH $\alpha$ had a semi-transparent appearance, an hexagonal outline and a diameter of about $25 \mathrm{~nm}$. It thus resembled other RNA-containing phages such as MS2 (Davis et al., 1961), Folac (Bradley et al., 1981 b), C-1 (Sirgel et al., 1981) or M (Coetzee et al., 1983). Phage preparations made by extracting confluently lysed double agar layer plates (see Methods) contained many examples of phage virions adsorbed uniformly along the lengths of IncHI or IncHII pili (Fig. 1).

Sensitivity to organic solvents or RNAase. The plaque-forming titre of a phage pilH $\alpha$ suspension was reduced by about $80 \%$ as a result of chloroform treatment, whereas the titre of phage C-1 was unaffected. The titre of phage $X$ was reduced by more than $99 \%$ following similar exposure. Titres of phage pilH $\alpha$ and the latter two phages were not reduced by diethyl ether treatment. Plaque formation by phages pilH $\alpha$ and $\mathrm{C}-1$ was totally inhibited by RNAase, whereas that of phage $\mathrm{X}$ was unaffected.

Host range. Although the control phages mentioned above plated on strains carrying their respective plasmids belonging to the Inc groups listed above, phage pilH $\alpha$ only formed plaques or propagated on bacterial strains carrying plasmids of the IncHI or HII groups (not shown and Table 1). It plated with equal efficiency (or propagated) on Klebsiella, E. coli, S. typhimurium, $P$. morganii and Sr. marcescens strains carrying any one of the $\mathrm{H}$-complex plasmids used (Table 1 and not shown). Plasmids of the IncHI subgroup have been reported as being repressed for pilus synthesis (Bradley et al., 1980, 1982a; Bradley, 1980 b; Taylor \& Levine, 1980; Taylor \& Grant, 1977) but the finding that phage pilH $\alpha$ plated on strains carrying R478 was not unexpected: plasmid R478 transferred at high frequencies and Taylor \& Levine (1980) reported an overnight transfer frequency of $9 \times 10^{-3}$ per organism. It may thus be assumed that the plasmid determines enough pili to support plaque formation (Meynell, 1978). Further correlation between plaque formation and transfer frequency was found with plasmid R27. This plasmid, which transferred at low frequencies (see above), did not allow the phage to plate, but a Tn7 insertional mutant (pDT933) of the plasmid, which transferred at much higher frequencies (see above; Taylor, 1983), permitted the phage to plate on strains harbouring it (Table 1). 


\section{Table 1. Host range of phage pilHa}

Drops of phage pilH $\alpha$ suspension (titre $1 \times 10^{16}$ p.f.u. $\mathrm{ml}^{-1}$ ) were spotted on lawns of organisms contained in top-layer agar. Incubation temperature was $26^{\circ} \mathrm{C}$. Phage propagation was done as described in Methods.

Host

E. coli JE2571(pHH1457)

S. typhimurium $\mathrm{M} 827-2(\mathrm{pHH} 1457)$

Sr. marcescens $\mathrm{Sr} 41$ ( $\mathrm{pHH} 1457)$

K. oxytoca G147(pHH1457)

E. coli JE2571(pHH1508a)

Sr. marcescens Sr4I-2(pHH1508a)

K. pneumoniae G162(pHH1508a)

E. coli J62-1( $\mathrm{pHH} 1532 \mathrm{~b}-1)$

S. t1phimurium M827-2(pHH1532b-1)

$K$. pneumoniae G162(pHH1532b-1)

K. oxjtoca G147(pMGI10)

E. coli J53-2(R27)

S. twphimurium M827-2(R27)

E. coli J53-2(pDT933)

S. typhimurium M827-2(pDT933)

Sr. marcescens Sr4I(pDT933)

P. morganii 2815nal-r(pDT933)

K. orytoca G147(pDT933)

E. coli J53(R726)

S. typhimurium M827-2(R726)

E. coli J53(R478)

Sr. marcescen.s Sr41-2(R478)

K. pneumoniae G162(R478)

P. morganii 2815nal-r(R478)

E. coli J53-2(pWR23)

S. typhimurium M827-2(pWR23)

Sr. marcescens Sr41-2(pWR23)

E. coli $\mathrm{J} 53$ (MIP233)

S. typhimurium M827-2(MIP233)

Sr. marcescens Sr4I-2(MIP233)
Phage action

Plasmid
Inc group* $\overbrace{\begin{array}{c}\text { Plaque } \\ \text { formation } \dagger \text { Propagation } \neq\end{array} \text { Plasmid reference }}$

\begin{tabular}{|c|c|c|c|}
\hline HII & + & ND & Bradley et al. (1982a) \\
\hline HII & + & ND & Bradley et al. (1982a) \\
\hline HII & + & ND & Bradley et al. (1982a) \\
\hline HII & + & ND & Bradley et al. (1982a) \\
\hline HII & + & ND & Bradley et al. (1982a) \\
\hline HII & + & ND & Bradley et al. (1982a) \\
\hline HII & + & ND & Bradley et al. (1982a) \\
\hline HII & + & ND & Bradley et al. (1982a) \\
\hline HII & + & ND & Bradley et al. (1982a) \\
\hline HII & + & ND & Bradley et al. (1982a) \\
\hline HII & + & ND & Wolfson et al. (1982) \\
\hline $\mathrm{HII}(\mathrm{HI})$ & - & + & Bradley et al. (1982a) \\
\hline HII (H1) & - & + & Bradley et al. (1982a) \\
\hline $\mathrm{HIl}(\mathrm{HI})$ & + & ND & Taylor (1983) \\
\hline HII (HI) & + & ND & Taylor (1983) \\
\hline HII (HI) & + & ND & Taylor (1983) \\
\hline $\mathrm{HII}(\mathrm{Hl})$ & + & ND & Taylor (1983) \\
\hline HII (H1) & + & ND & Taylor (1983) \\
\hline $\mathrm{HII}(\mathrm{HI})$ & - & + & Bradley et al. (1982a) \\
\hline $\mathrm{HII}(\mathrm{HI})$ & - & + & Bradley et al. (1982a) \\
\hline $\mathrm{HI} 2(\mathrm{H} 2)$ & + & ND & Taylor \& Levine (1980) \\
\hline $\mathrm{HI} 2$ (H2) & + & ND & Taylor \& Levine (1980) \\
\hline $\mathrm{H} 12(\mathrm{H} 2)$ & + & ND & Taylor \& Levine (1980) \\
\hline $\mathrm{HI} 2$ (H2) & + & ND & Taylor \& Levine (1980) \\
\hline $\mathrm{H} 12(\mathrm{H} 2)$ & - & + & Taylor \& Levine (1980) \\
\hline $\mathrm{H} 12(\mathrm{H} 2)$ & - & + & Taylor \& Levine (1980) \\
\hline $\mathrm{H} 12$ (H2) & - & + & Taylor \& Levine (1980) \\
\hline $\mathrm{HI} 3$ (H3) & - & + & Taylor \& Levine (1980) \\
\hline $\mathrm{HI} 3(\mathrm{H} 3)$ & - & + & Taylor \& Levine (1980) \\
\hline HI3 (H3) & - & + & Taylor \& Levine (1980) \\
\hline
\end{tabular}

* The former Inc subgroup (see Bradley et al., 1982a) is given in parentheses.

++ . Plaque formation to titre: - , no visible action.

++ , At least a 10 -fold phage titre increase above that of the negative control obtained on two separate occasions: ND, not done.

\section{DISCUSSION}

Phage pilH $\alpha$ is the first wild-type bacteriophage reported to be temperature sensitive for plaque formation. The mechanism, which is also expressed with IncHII plasmids which are not temperature sensitive for transfer (see above) remains to be ascertained. The reason why the phage was detected in the first instance with the use of $37^{\circ} \mathrm{C}$ incubators was probably that bench incubators were usually filled to capacity with plates from the bench at the end of a day for overnight incubation. Under these conditions it takes hours for agar in the plates to reach $37{ }^{\circ} \mathrm{C}$ and plates will remain below $30^{\circ} \mathrm{C}$ for long enough to allow a temperature sensitive system to develop significantly. Inconsistencies arose when the agar was temperature equilibrated in a much shorter period as a result of a $37^{\circ} \mathrm{C}$ incubator containing a small number of plates.

Phage M (Coetzee et al., 1983) was the first RNA-containing phage described which adsorbed to thick rigid pili. The fact that it differed from all other RNA phages in being sensitive to chloroform was thus not totally unexpected. This does not apply to the chloroform sensitivity of phage pilH $\alpha$ as all other RNA-containing phages which adsorb to specific thick flexible pili like C-1 (Sirgel et al., 1981), MS2 (Davis et al., 1961), t (Bradley et al., 1981 c) and $\mathrm{F}_{\mathrm{o}}$ lac (Bradley et 
$a l ., 1981 b$ ) are chloroform resistant. The degree of chloroform sensitivity of phage pilH $\alpha$, like that of phage $\mathrm{M}$, is less than that of suspensions of the lipid-containing phages belonging to the families Tectiviridae, Corticoviridae or Cystoviridae (Matthews, 1982), which are nearly totally inactivated under comparable conditions (Coetzee et al., 1979; Wong \& Bryan, 1978; Bradley \& Rutherford, 1975; Vidaver et al., 1973; Mindich, 1978). The RNA-containing phages also differ from phages of the above three families in that they are resistant to diethyl ether.

RNA-containing phages adsorb uniformly to the sides of shafts of sex pili or towards the distal tip only (Bradley et al., $1981 b, c)$. They are usually specific for plasmids of one particular incompatibility group (see Coetzee et al., 1979, 1983). Exceptions occur with plasmids of IncF subgroups I-IV which constitute the F-complex. The pili coded for by these groups of plasmids are serologically related (Lawn \& Meynell, 1970) and some RNA phages like MS2 or Q $\beta$ plate on strains carrying plasmids belonging to any of these groups (Dennison \& Hedges, 1972). Phage pilH $\alpha$, by plating on bacterial strains carrying either HI or HII plasmids (Table 1), is thus in a rather analogous position to that of phages MS2 and $\mathrm{Q} \beta$ and lends support to the arrangement (see Bradley et al., 1982a) of $\mathrm{H}$ plasmids into Inc groups HI and HII.

Professor Naomi Datta supplied many of the strains and advice at all times. The technical assistance of Monica Tweehuysen and Sarel van Biljon is gratefully acknowledged. D.E. B. acknowledges the support of the Medical Research Council of Canada (Grant no. MT5608).

\section{REFERENCES}

Ackermann, H.-W., Audurier, A., Berthiaume, L., Jones, L. A., Mayo, J. A. \& Vidaver, A. K. (1978). Guidelines for bacteriophage characterization. Adrances in Virus Research 23, 1-24.

ANDERSON, E. S. (1975). The problem and implications of chloramphenicol resistance in the typhoid bacillus. Journal of Hygiene 74, $289-299$.

ANDERSON, E. S. \& SMITH, H. R. (1972). Chloramphenicol resistance in the typhoid bacillus. British Medical Journal 3, 329-331.

Anderson, E. S., Humphreys, G. O. \& Willshaw, G. A. (1975). The molecular relatedness of $R$ factors in Enterobacteria of human and animal origin. Journal of General Microbiology 91, 376-382.

Bradley, D. E. $(1980 a)$. Determination of pili by conjugative bacterial drug resistance plasmids of incompatibility groups $\mathrm{B}, \mathrm{C}, \mathrm{H}, \mathrm{J}, \mathrm{K}, \mathrm{M}, \mathrm{V}$ and $\mathrm{X}$. Journal of Bacteriology 141, 828-837.

BRadLEY, D. E. (1980 h). Morphological and serological relationships of conjugative pili. Plasmid 4, 155169.

Bradley, D. E. \& Fleming, J. (1983). Incompatibility group identification for repressed plasmids using host cell lysis by specific bacteriophages. Journal of Microbiological Methods 1, 171-176.

Bradley, D. E. \& Rutherford, E. L. (1975). Basic characterization of a lipid-containing bacteriophage specific for plasmids of the $\mathrm{P}, \mathrm{N}$, and $\mathrm{W}$ compatibility groups. Canadian Journal of Microbiology 21, 152-163.

Bradley, D. E., Taylor, D. E. \& Cohen, D. R. (1980). Specification of surface mating systems among conjugative drug resistance plasmids in Escherichia coli K-12. Journal of Bacteriology 143, 1466-1470.

Bradley, D. E., Coetzee, J. N., Bothma, T. \& Hedges, R. W. (1981a). Phage X: a plasmiddependent, broad host range, filamentous bacterial virus. Journal of General Microbiology 126, 389-396.

Bradley, D. E., Coetzee, J. N., Bothma, T. \& Hedges, R. W. $(1981 b)$. Phage $F_{0} l a c$ : an $F_{0} l a c$ plasmid-dependent bacteriophage. Journal of General Microbiolog! 126, 405-411.

Bradley, D. E., Coetzee, J. N., Bothma, T. \& Hedges, R. W. $(1981 c)$. Phage t: a group T plasmiddependent bacteriophage. Journal of General Microbiolog! 126, 397-403.

Bradley, D. E., Hughes, V. M., Richards, H. \& DATTA, N. (1982a). R plasmids of a new incompatibility group determined constitutive production of $\mathrm{H}$ pili. Plasmid 7, 230-238.

Bradley, D. E., Sirgel, F. A., Coetzee, J. N., Hedges, R. W. \& Coetzee, W. F. (1982b). Phages C-2 and $\mathrm{J}$ : IncC and IncJ plasmid-dependent phages, respectively. Journal of General Microbiology 128, $2485-2498$.

Coetzee, J. N. (1974). Properties of Proteus and Providence strains harbouring recombinant plasmids between P-lac and R $1 d r d 19$ or R447b. Journal of General Microbiology 80, 119-130.

Coetzee, J. N., Lecatsas, G., Coetzee, W. F. \& Hedges, R. W. (1979). Properties of R plasmid R772 and the corresponding pilus-specific phage PR772. Journal of General Microbiology 110, 263-273.

Coetzee, J. N., Sirgel, F. A. \& Lecatsas, G. (1980). Properties of a filamentous phage which adsorbs to pili coded by plasmids of the IncI complex. Journal of General Microbiology 117, 547-551.

Coetzee, J. N., Bradley, D. E. \& Hedges, R. W. (1982). Phages $I \alpha$ and $I_{2}-2$ : IncI plasmid-dependent bacteriophages. Journal of General Microbiology 128, 2797-2804.

Coetzee, J. N., Bradley, D. E., Hedges, R. W., Fleming, J. \& Lecatsas, G. (1983). Bacteriophage $\mathbf{M}$ : an incompatibility group $\mathbf{M}$ plasmid-specific phage. Journal of General Microbiology 129, 22712276.

DatTA, N. (1977). Classification of plasmids as an aid to understanding their epidemiology and evolution. Journal of Antimicrobial Chemotherapy 3 (suppl. C), $19-23$.

Datta, N. (1979). Plasmid classification: incompati- 
bility grouping. In Plasmids of Medical, Entironmental and Commercial Importance, pp. 3-12. Edited by K. M. Timmis \& A. Puhler. Amsterdam: Elsevier/ North Holland Biomedical Press.

DatTA, N. \& Hedges, R. W. (1972). Host ranges of R factors. Journal of General Microbiology 70, 453-460.

Datta, N., Dacey, S., Hughes, V., Knight, S., Richards, H., Williams, G., Casewell, M. \& ShanNon, K. P. (1980). Distribution of genes for trimethoprim and gentamicin resistance in bacteria and their plasmids in a general hospital. Journal of General Microhiology 118, 495-508.

Davis, J. E., Strauss, H. J. \& Sinsheimer, R. L. (1961). Bacteriophage MS2: another RNA phage. Science 134, 1427.

Dennison, S. \& Hedges, R. W. (1972). Host specificities of RNA phages. Journal of Hygiene 70, 55-61.

EdITORIAL. (1983). Phage therapy. Lancet ii, 12871288.

Grindley, N. D. F., Grindley, J. N. \& Anderson, E. S. (1972). R factor compatibility groups. Molecular and General Genetics 119, 287-297.

Hedges, R. W. \& JACOBY, G. A. (1980). Compatibility and molecular properties of plasmid Rmsl49 in Pseudomonas aeruginosa and Escherichia coli. Plasmid 3. 1.6.

Hershey, A. D., Kalmanson, G. \& BronfenbrenNER, J. (1943). Quantitative methods in the study of the phage-antiphage reaction. Journal of Immunologl 46. 267276

Jacob, A. E., Shapiro, J. A., Yamamoto, L., Smith, D. I., Cohen, S. N. \& Berg, D. (1977). Plasmid studies in Escherichia coli and other enteric bacteria. In DNA Insertion Elements, Plasmids and Episomes, pp. 607638 . Fdited by A. I. Bukhari, J. A. Shapiro \& S. L. Adhya. New York: Cold Spring Harbor Laboratory.

LAWn, A. M. \& Meynell, E. (1970). Serotypes of sex pili. Journal of Hyiene 68, 683694.

Le Minor, L., Coynault, C., Chabbert, Y., GerBaus, G. \& Le Minor, S. (1976). Compatibility groups of metabolic plasmids. Annales de Microbiotogie 127B, 31-40.

Matsumoto, H., Tazaki, T. \& Hosogaya, S. (1973). A generalized transducing phage of Serratia marcescens. Japanese Journal of Microbiology 17, 473 479.

Matthews, R. E. F. (1982). Classification and nomenclature of viruses. Fourth report of the International Committee on Taxonomy of Viruses. Intertirology 17, 1-200.

Meynell, E. (1978). Experiments with sex pili: an investigation of the characters and function of F-like and I-like sex pili based on their reactions with antibody and phage. In Pili, pp. 207-233. Edited by D. E. Bradley, F. Raizen, P. Fives-Taylor \& J. Ou. Washington, DC: International Conferences on Pili.

Meynell, G. G. \& Lawn, A. M. (1968). Filamentous phage specific for the I sex factor. Nature, London 217, 1184-1186.

MiNDICH, L. (1978). Bacteriophages that contain lipid. In Comprehensive Virology, vol. 12, pp. 271-335. Edited by C. Fraenkel-Conrat \& A. M. Wagner. New York: Plenum.
Roussel, A. F. \& Chabbert, Y. A. (1978). Taxonomy and epidemiology of Gram-negative bacterial plasmids studied by DNA-DNA filter hybridization in formamide. Journal of General Microbiology 104, 269-276.

Sirgel, F. A., Coetzee, J. N., Hedges, R. W. \& LeCatsas, G. (1981). Phage $\mathrm{C}-1$ : an IncC group plasmid-specific phage. Journal of General Microbiology 122, 155-160.

Smith, H. R., Grindley, N. D. F., Humphreys, G. O. \& ANDERSON, E. S. (1973). Interactions of group H resistance factors with the $\mathrm{F}$ factor. Journal of Bacteriology 115, 623-628.

Spratt, B. G., Rowbury, R. H. \& Meynell, G. G. (1973). The plasmid of Salmonella typhimurium LT2. Molecular and General Genetics 121, 347-353.

TAYLOR, D. E. (1983). Transfer-defective and tetracycline-sensitive mutants of the incompatibility group HI plasmid R27 generated by insertion of transposon 7. Plasmid 9, 227-239.

TAYLOR, D. E. \& GRANT, R. B. (1976). Inhibition of bacteriophage Lambda, T1, and T7 development by $\mathrm{R}$ plasmids of the $\mathbf{H}$ incompatibility group. Antimicrobial Agents and Chemotherapy 10, 762-764.

TAYLOR, D. E. \& GRANT, R. B. (1977). R plasmids of the $\mathrm{S}$ incompatibility group belong to the $\mathrm{H} 2$ incompatibility group. Antimicrobial Agents and Chemotherapy 12, 431-434.

TAYLOR, D. E. \& Levine, J. G. (1980). Studies of temperature-sensitive transfer and maintenance of $\mathrm{H}$ incompatibility group plasmids. Journal of General Microhiology 116, 475484.

VidaVer, A. K., Koski, R. K. \& VAN EtTen, J. L. (1973). Bacteriophage $\phi 6$ : a lipid-containing virus of Pseudomonas phaseolicola. Joturnal of Virology 11 , 799. 805

Williams Smith, H. (1974). Thermosensitive transfer factors in chloramphenicol-resistant strains of $\mathrm{Sal}$ monella typhi. Lancet ii, 281-282.

Williams Smith, H. \& Huggins, M. B. (1983). Effectiveness of phages in treating experimental Escherichia coli diarrhoea in calves, piglets and lambs. Journal of General Microbiology 129, 2659 2675.

Williams Smith, H., Parsell, Z. \& Green, P. (1978). Thermosensitive antibiotic resistance plasmids in Enterobacteria. Journal of General Microbiology 109. 3747

Wolfson, J. S., Hooper, D. C., Swartz, M. N. \& MCHUGH. G. L. (1982). Antagonism of the B subunit of DNA gyrase eliminates plasmids pBR322 and pMG110 from Escherichia coli. Journal of Bacteriology 152, 338-344.

WONG, F. H. \& Bryan, L. E. (1978). Characteristics of PR5, a lipid-containing plasmid-dependent phage. Canadian Journal of Microhiology 24, 875-882.

Yamamoto, K. R., Alberts, B. M., Benzinger, R., LAWHORNE, L. \& Treiber, G. (1970). Rapid bacteriophage sedimentation in the presence of polyethylene glycol and its application to large-scale virus purification. Virology 40, 734-744. 